\title{
Jan Bień
}

prof. dr hab. inż.

Politechnika Wrocławska

Wydział Budownictwa Lądowego i Wodnego

jan.bien@pwr.edu.pl

DOI: 10.35117/A_ENG_21_01_01

\section{Characteristic degradation processes and defects of reinforced concrete bridges}

\begin{abstract}
The unambiguous identification of degradation processes and the damage they cause is a very important part of the diagnostics of bridge facilities and, as a result, has a fundamental impact on the efficient management of the maintenance and operation of transport infrastructure. The paper provides an overview of the degradation phenomena characteristic for reinforced concrete bridges, as well as a classification of degradation stimulators and degradation mechanisms showing their mutual conditions. The characteristics of typical degradation processes, usually combinations of two or more degradation mechanisms, are also presented. A hierarchical multi-level classification of damage to the bridge structure type concerned was proposed, as well as the relationship between the most common degradation mechanisms and class-specific damage was shown.
\end{abstract}

Keywords: Reinforced concrete bridges; Degradation stimulators; Degradation mechanisms; Degradation processes; Damage

\section{Introduction}

Effective management of the operation and maintenance of transport infrastructure, including in particular the bridge infrastructure, requires ongoing monitoring of the condition of the facilities. Decisions must be made throughout the life of the bridge structure, and their type and scope depend on the applicable regulations and the current condition of the structure. The basis for the assessment of the condition is the results of systematic diagnostic activities including reviews and various types of tests, the purpose of which is to detect as well as qualitatively and quantitatively identify possible damage to the object and the degradation processes causing such damage [1, 2, 3].

The degradation process can be defined as a factor causing the deterioration of the condition of the object resulting from the activity of the degradation mechanism or mechanisms, where the degradation mechanism may be a physical, chemical, or biological phenomenon causing damage or damage to the object. The factors that can generally be described as degradation stimulants are responsible for the initiation, course, and speed of development of degradation processes. These stimulators activate the mechanisms that make up the final form of the bridge structure degradation process, and by acting during the degradation process - they influence its course. The links between stimulators, mechanisms, and degradation processes with damages are shown schematically in Fig. 1.

Fig. 1:

In the diagnostics of bridge structures, three levels of detail can be distinguished, shown in

- damage diagnostics - including the detection and identification of damage to the object, with the determination of their location, extent, and intensity,

- degradation process diagnostics - dealing with the identification of degradation mechanisms that make up the degradation process, 
- degradation stimulators diagnostics - aimed at determining the factors influencing the initiation and course of degradation phenomena.

- Comprehensive diagnostic activities should cover all three levels of detail mentioned above, but in practice, it is difficult to obtain satisfactory results in all areas. This is due to the high complexity of the degradation phenomena occurring.

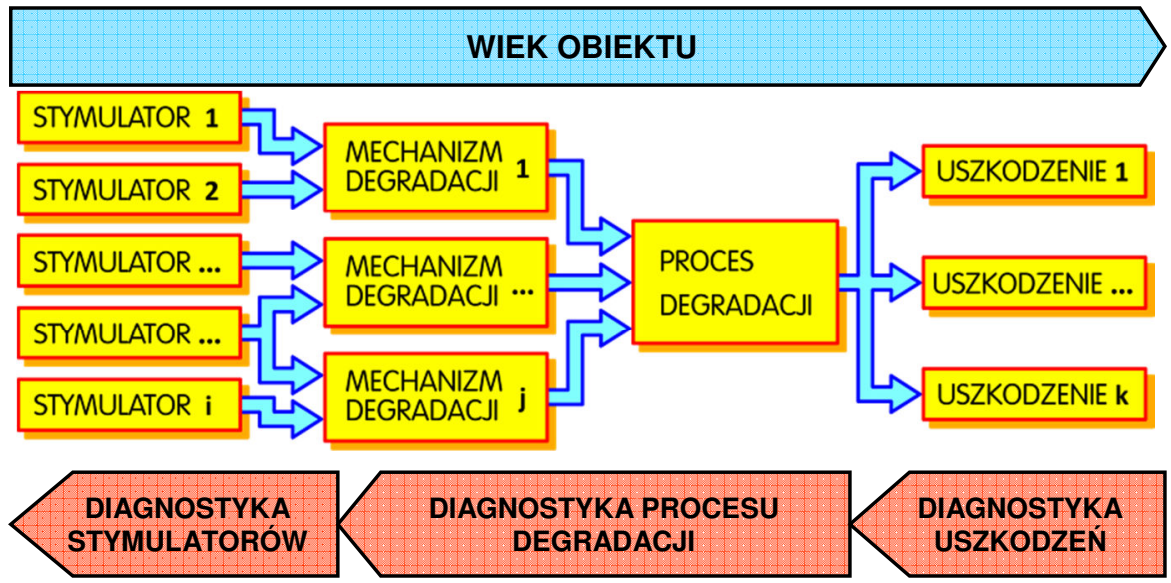

1. Components of degradation phenomena causing damage to bridges and diagnostic procedures

\section{Bridge objects degradation Degradation stimulants}

The most common and most significant stimulants influencing the mechanisms and processes of degradation of bridge structures can be divided into (Fig. 2):

- stimulants related to human activities,

- stimulants related to generally understood environmental impacts,

- stimulators partly related to human activity and partly due to environmental influences.

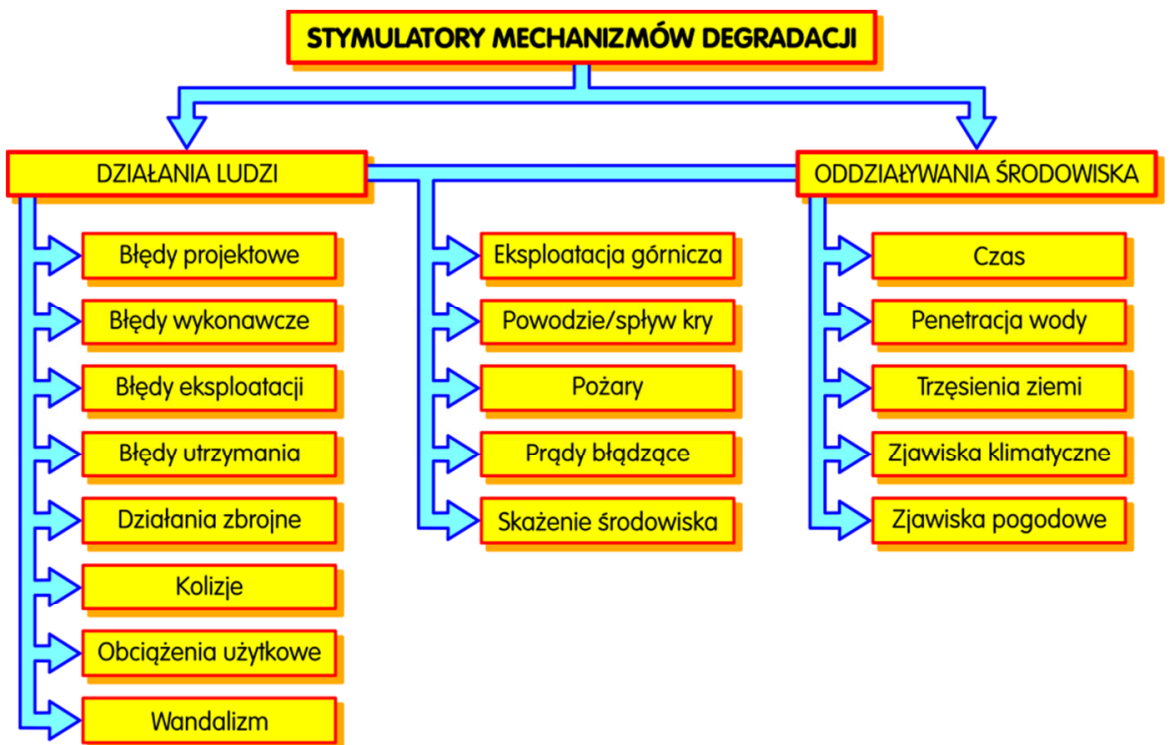

2. Basic factors stimulating the mechanisms of degradation of bridge structures [3] 
Some types of fires, environmental contamination, or mining exploitation, which are usually initiated by human activities, but are influenced by bridge structures through changes in their environmental conditions, are examples of the influence of the combined actions of people and the environment on degradation phenomena.

\section{Degradation mechanisms}

The most common degradation mechanisms of bridge structures are presented in Fig. 3.

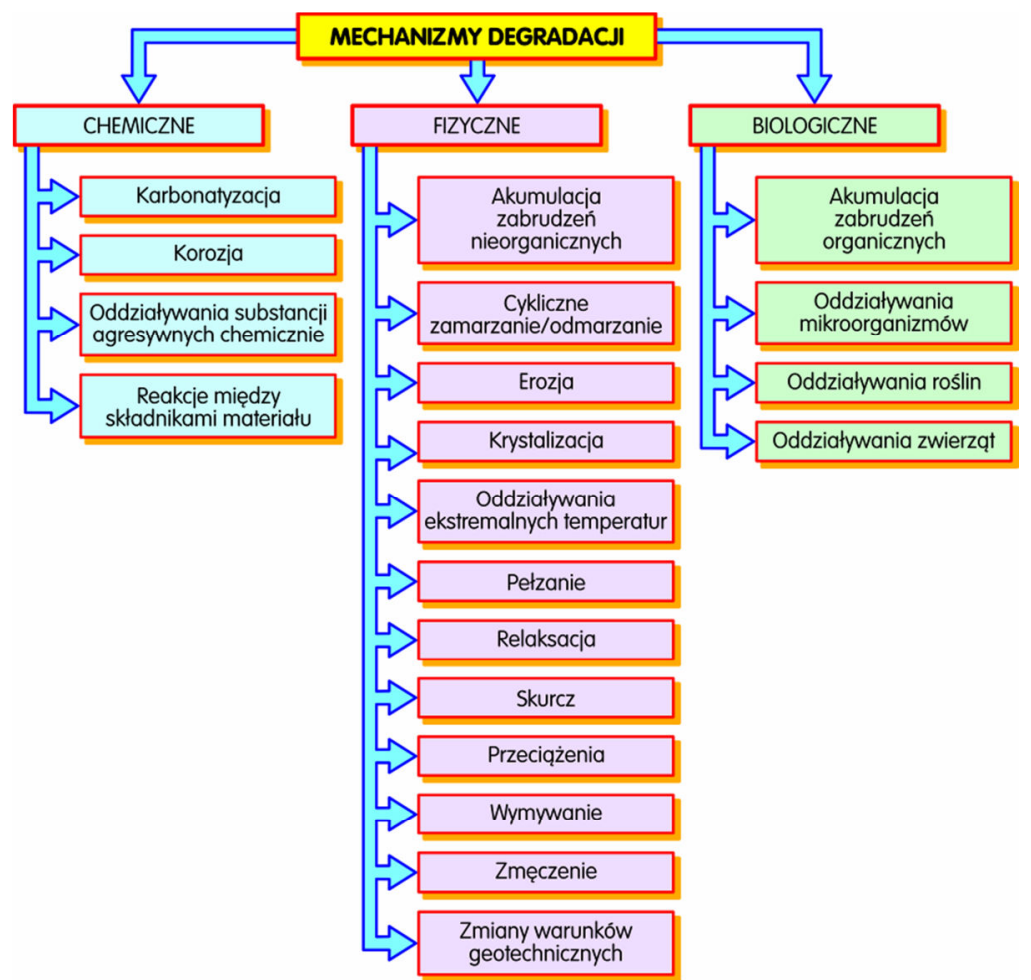

3. Classification of the basic degradation mechanisms of bridge structures [3]

The degradation mechanisms are activated by stimulators, which also affect the course and intensity of degradation phenomena, and the final form of the degradation of a bridge structure is usually determined by a combination of active degradation mechanisms (see Fig. 1) shaping the individual degradation process, specific for each object.

From the point of view of the nature of degradation phenomena, we can distinguish three basic groups of degradation mechanisms occurring in bridge structures (Fig. 3):

- chemical mechanisms causing object degradation as a result of chemical reactions,

- physical mechanisms leading to damage as a result of physical phenomena,

- biological mechanisms related to the influence of biological factors on bridge structures.

\section{Physical degradation mechanisms}

Physical phenomena form the largest set of mechanisms contributing to the degradation of bridge structures. With regard to reinforced concrete bridge structures, potentially all the physical degradation mechanisms listed in the list are of significant importance, and their connections with individual stimulators are presented in Tab. 1. 
Tab. 1. Stimulants and bridge structures physical degradation mechanisms

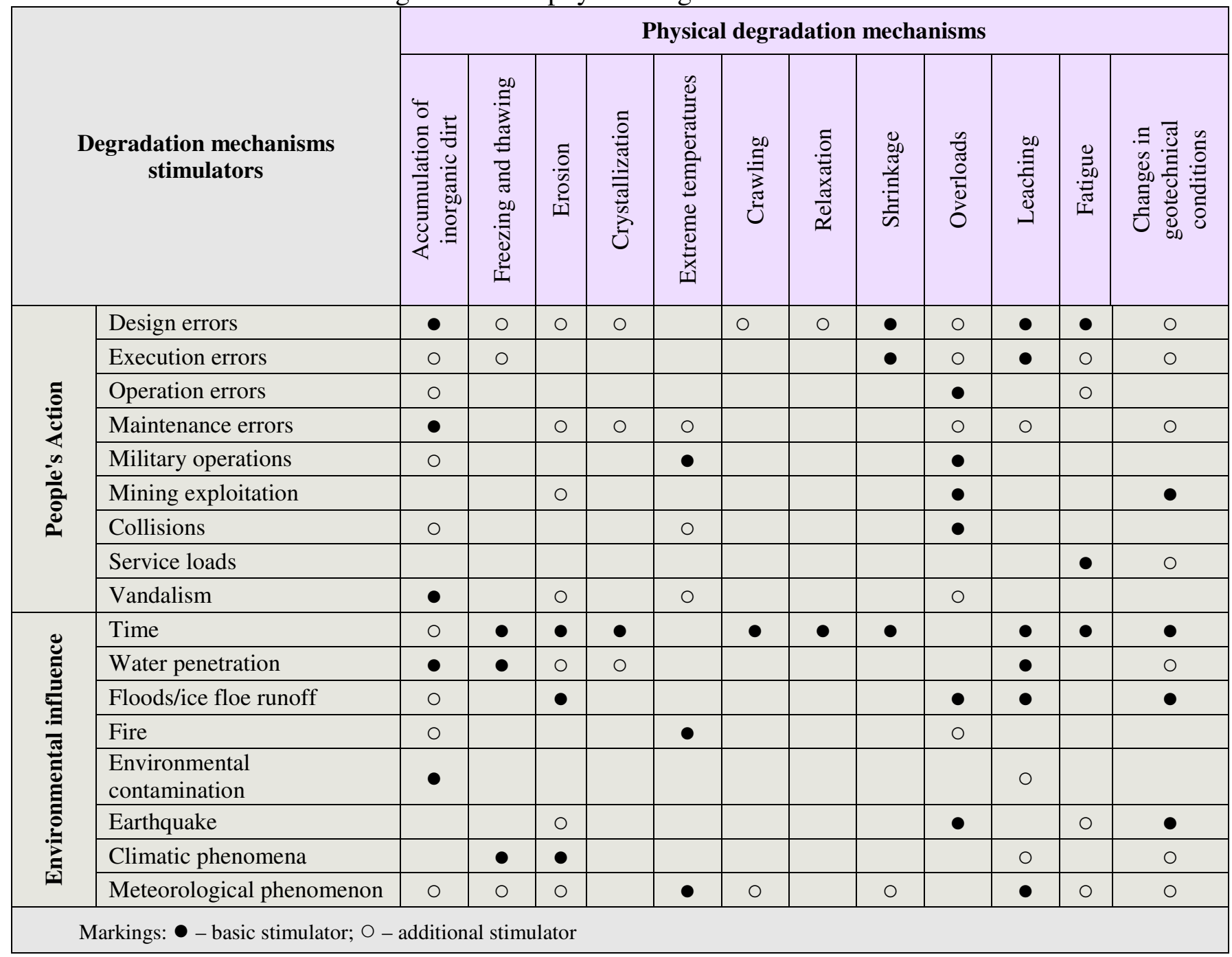

Physical degradation mechanisms constitute the largest group of mechanisms influencing reinforced concrete bridge structures - 12 of the most common ones are distinguished in Fig. 3. The individual mechanisms are characterized in detail, among others in the works $[3,6,8,9,10,11,14,15,18,19,23,33,34,35]$

\section{Chemical degradation mechanisms}

Fig. 3 distinguishes four groups of chemical degradation mechanisms, and their sensitivity to the effects of degradation stimulators is presented in Tab. 2. In reinforced concrete structures, one of the basic chemical degradation mechanisms of bridge structures is the carbonization of concrete $[8,9,10,16,28,32,33]$. This mechanism is related to the presence of active gases and ions in the water, mainly carbon dioxide, which forms a weak carbonic acid solution with water. The reaction of calcium hydroxide contained in the concrete with carbonic acid leads to the formation of calcium carbonate, and as a result, reduces the $\mathrm{pH}$ value and the protective properties of the concrete cover of the reinforcement of the element.

Corrosion $[3,6,8,15,25,29,30,36]$ is a common and very dangerous degradation mechanism concerning steel components of reinforced concrete structures metals caused by external factors. 
Tab. 2. Stimulants and chemical degradation mechanisms of bridge structures

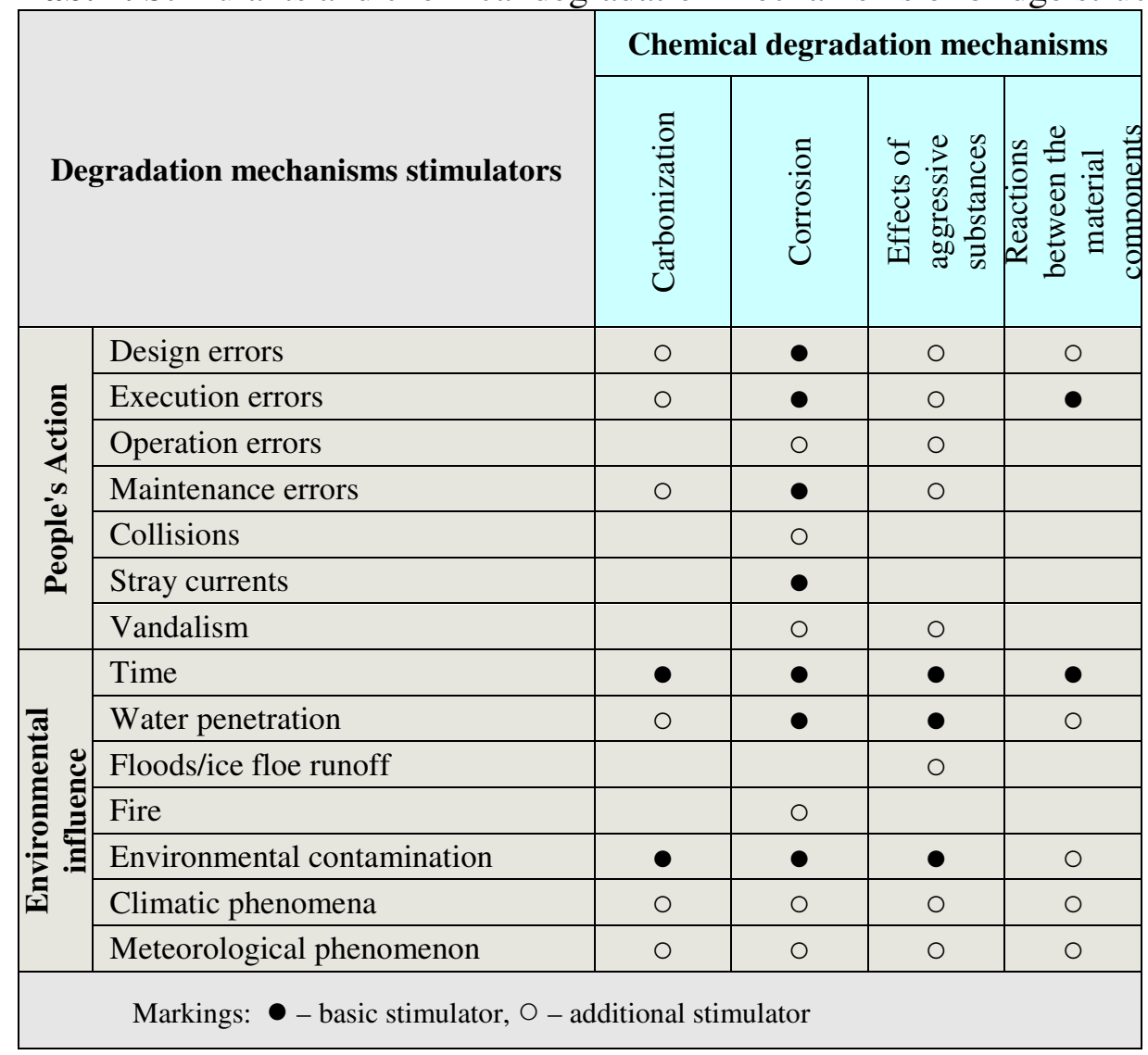

Another group of degradation mechanisms is formed by the interactions of chemically aggressive substances (e.g. [11, 17]), causing reactions between externally acting chemically active substances, such as: acids, bases, salts, fats, etc., and the material of the object.

The last large group of chemical degradation mechanisms includes reactions between the components of the material of the elements of the bridge structure. These are the most common mechanisms that cause the degradation of concrete elements as a result of chemical reactions between the aggregate grains and the cement matrix as a result of an incorrect choice of material composition (e.g. [23, 28]). This group also includes photochemical reactions - initiated by sunlight - causing, for example, color changes (fading or darkening) of shells on structural elements.

\section{Biological degradation mechanisms}

The phenomena of biological degradation, also called biodeterioration, can be defined according to $[24,38]$ as undesirable changes in material properties caused by the activity of living organisms. Biodeterioration has a relatively limited, but in many situations difficult to ignore, impact on reinforced concrete bridge structures. The four basic types of degradation mechanisms related to the influence of biological factors are presented in Fig. 3, where the following are distinguished: the accumulation of organic dirt, the influence of microorganisms, the influence of plants, and the influence of animals.

The relationships between the biological mechanisms of degradation and their stimulators are presented in tab. 3. The phenomena occurring as a result of biological factors acting on bridge structures can be generally divided into the following groups [37]: 
- mechanical impacts consisting in the direct action of organisms on the elements of the object, e.g. displacement of wall elements as a result of penetration of plant roots into joints, material losses caused by rodents,

- chemical assimilation biodeterioration - caused by the use of the object's materials as a nutrient by living organisms,

- chemical dissimilation biodeterioration - as a result of the harmful effect of metabolites of living organisms on the the bridge structure elements,

- accumulation of living organisms on the surface of the object, causing deterioration of its working conditions (e.g. maintaining increased humidity), appearance, and often also functional values (e.g. limiting the possibility of bearing displacement).

Tab. 3. Stimulants and biological degradation mechanisms of bridge structures

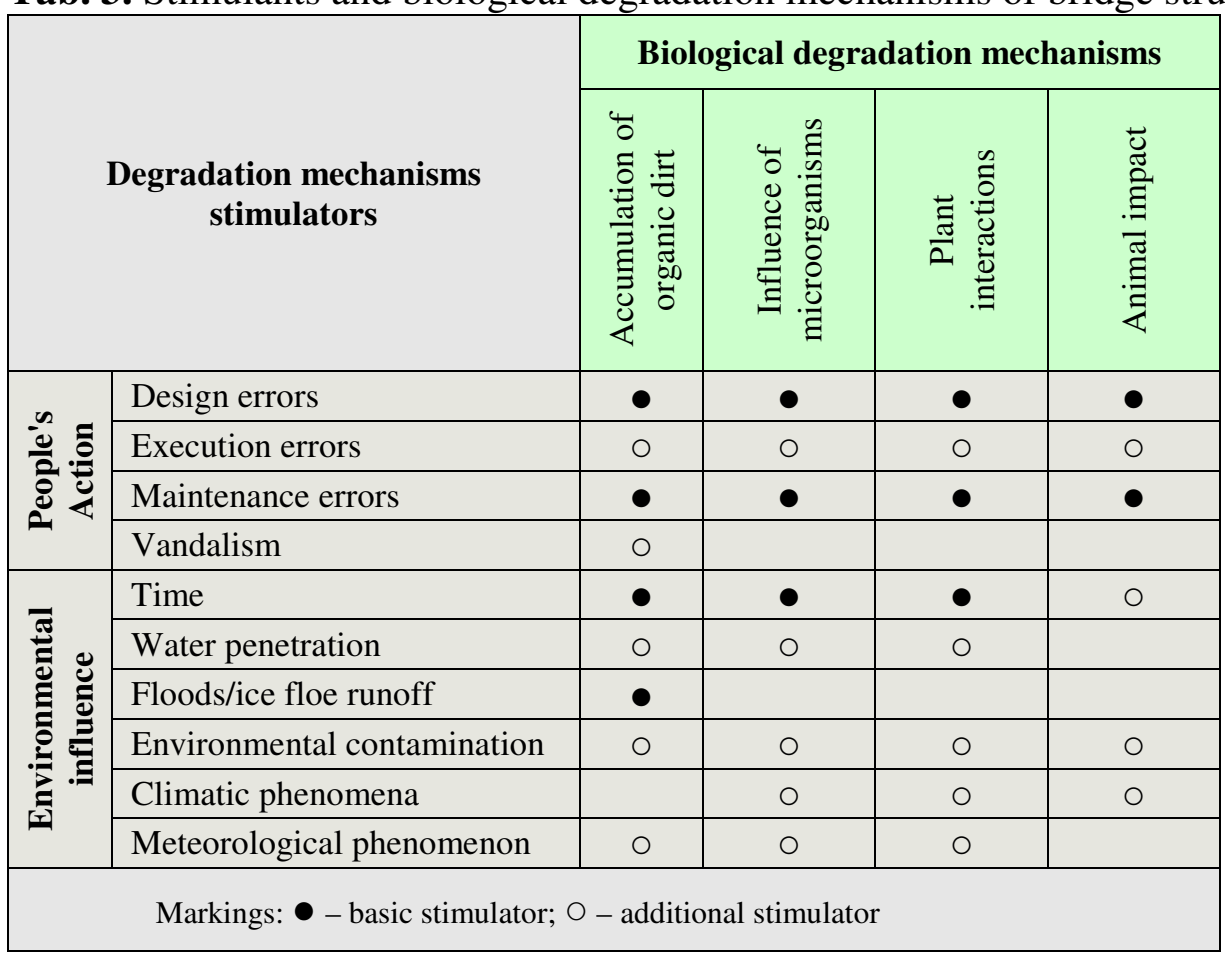

\section{Characteristic degradation processes of reinforced concrete bridge objects Processes of corrosive material degradation}

The processes of corrosive material degradation are the dominant phenomena in relation to reinforced concrete structures, related to the corrosion of the reinforcement causing destruction, losses, loss of material continuity, and often leading to the contamination of the structural elements with corrosion products (Fig. 4). In the processes of corrosive degradation of reinforced concrete structures (Fig. 5), the corrosion mechanism is usually associated with the phenomenon of carbonation, or more generally - concrete neutralization, and with the effects of other chemically aggressive substances (chlorides, sulfates, nitrates, etc.). The course of corrosion phenomena may also be influenced by the possible accumulation of pollutants and the impact of biological mechanisms (microorganisms, plants), which primarily affect the persistence of longterm moisture in the structure, which accelerates and intensifies the course of corrosion processes. The basic mechanisms leading to the activation of the process of corrosive degradation of reinforced concrete bridge structures are: penetration of carbon dioxide $\mathrm{CO}_{2}$ in the air, penetration of $\mathrm{Cl}$ - chloride ions most often associated with the use of sodium chloride $\mathrm{NaCl}$ for winter road maintenance, as well as water penetration into concrete. 


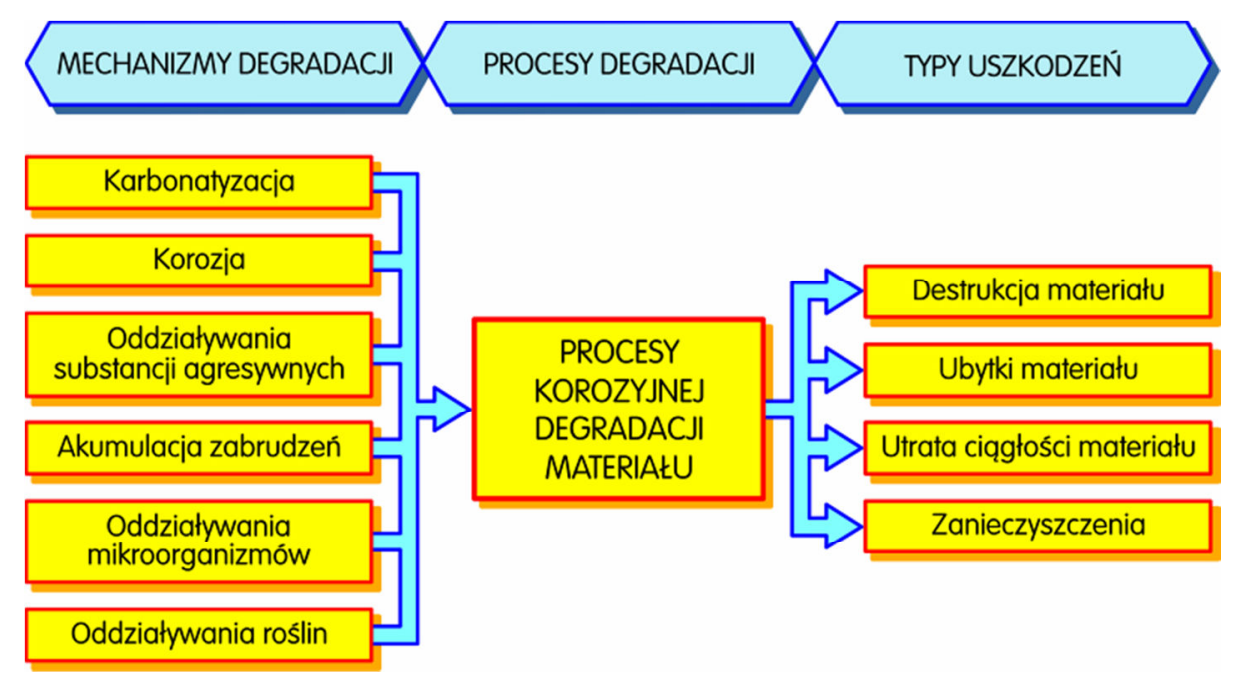

4. Basic mechanisms related to the processes of corrosive degradation of reinforced concrete bridge structures and characteristic types of damage [3]

The corrosion degradation process, proceeding from the surface to the depth of the element, causes gradual carbonization of the external concrete layers, and as a result, lowers the $\mathrm{pH}$ value and the protective properties of the concrete cover. The characteristic ranges of the $\mathrm{pH}$ value of concrete in connection with its protective effect in relation to the reinforcement are presented in tab. 4. Lowering the $\mathrm{pH}$ value to 10 creates conditions for the initiation of the corrosion process of the reinforcement, and the $\mathrm{pH} \leq 9$ proves the complete carbonation of the concrete and the loss of the protective properties of the cover (e.g. [12, 15, 27]). In the subsequent stages of the corrosion degradation process, there are scratches (Fig. 5a), fractures (Fig. 5b), local losses of the concrete cover (Fig. 5c), and in the extreme case - losses of the material of the reinforcement bars leading to their breakage (Fig. 5d).

Tab. 4. Influence of the $\mathrm{pH}$ value of concrete on its protective properties in relation to the reinforcement $[12,15]$

\begin{tabular}{|c|l|}
\hline $\begin{array}{c}\text { Concrete } \mathbf{p H} \\
\text { value }\end{array}$ & \multicolumn{1}{c|}{$\begin{array}{c}\text { Effectiveness of anti-corrosion reinforcement } \\
\text { protection }\end{array}$} \\
\hline $\mathbf{1 3 , 5 - 1 1 , 8}$ & $\begin{array}{l}\text { Full protection of the reinforcement, non-carbonated } \\
\text { concrete }\end{array}$ \\
\hline $\mathbf{1 1 , 8 - 1 1 , 0}$ & $\begin{array}{l}\text { The initial phase of reducing the protective properties of } \\
\text { concrete }\end{array}$ \\
\hline $\mathbf{1 1 , 0 - 1 0 , 0}$ & $\begin{array}{l}\text { Further loss of protective properties and the risk of the } \\
\text { reinforcement corrosion initiation }\end{array}$ \\
\hline$\leq \mathbf{1 0 , 0}$ & $\begin{array}{l}\text { Significant loss of protective properties of concrete, } \\
\text { initiation, and development of the reinforcement } \\
\text { corrosion process }\end{array}$ \\
\hline$\leq \mathbf{9 , 0}$ & $\begin{array}{l}\text { Lack of protective properties of concrete, advanced } \\
\text { reinforcement corrosion }\end{array}$ \\
\hline
\end{tabular}



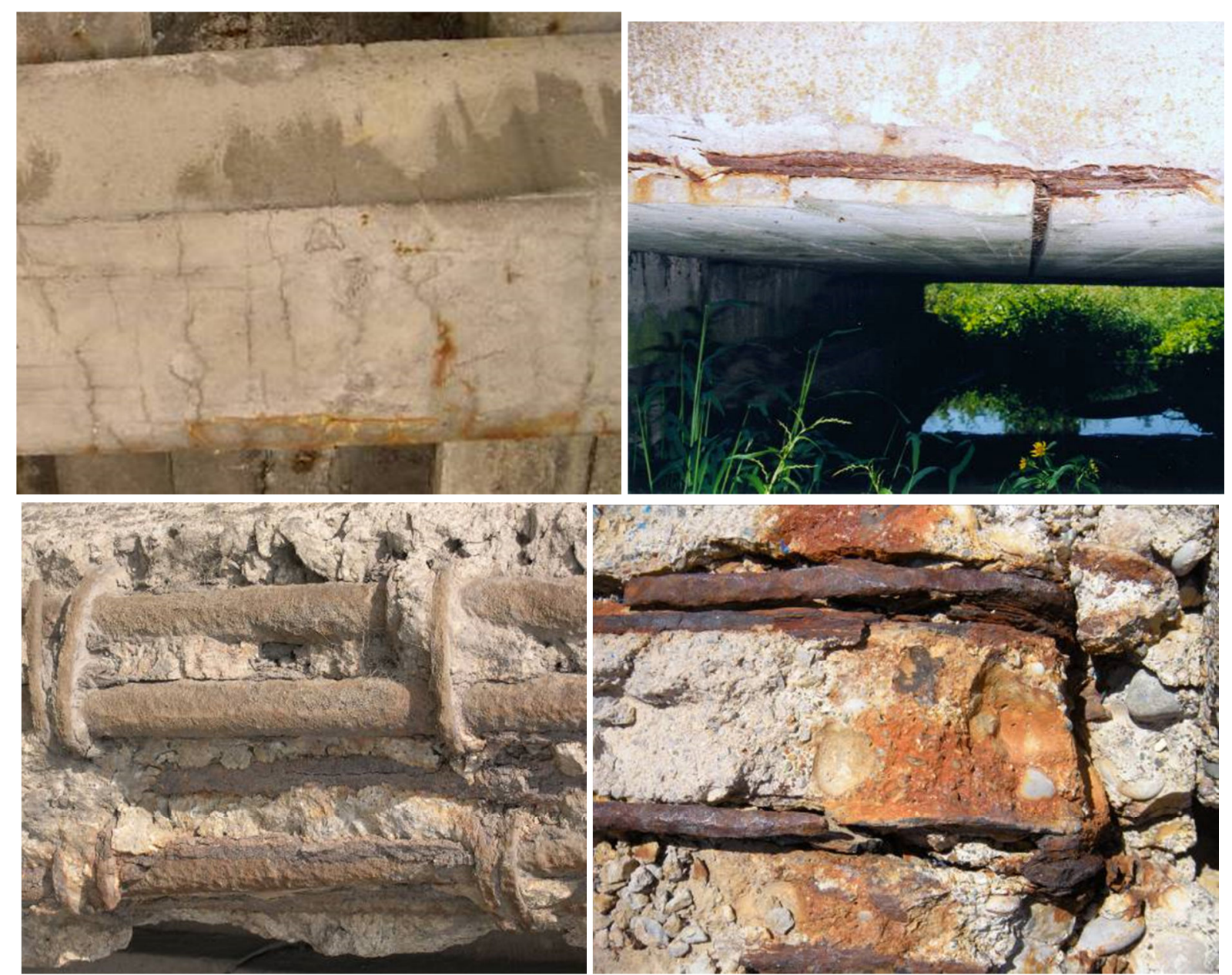

5. Characteristic effects of corrosion degradation processes in reinforced concrete structures:

a) cover scratches and leakage of reinforcement corrosion products,

b) cover fractures and detachment,

c) cover losses and exposed reinforcement bars,

d) losses of reinforcement bar material leading to breakage of their continuity

Corrosion products of reinforcing bars are a mixture of various chemical compounds, the volume of which can be significant, even more than five times (Tab. 4), greater than the volume of steel from which they were made $[8,13]$, which contributes to the accelerated destruction of the concrete cover.

\section{Processes of destructive material degradation}

The processes of destructive material degradation cause deterioration of the physical or chemical properties of concrete, as well as loss of continuity and loss of concrete as a result of the impact, other than corrosion, of external factors and processes taking place in the material (Fig. 6). Physical mechanisms are important here, in particular, cyclical freezing and thawing of water in the pores of the concrete, the formation and growth of crystals and concrete shrinkage causing internal stresses in the material, rheological processes, and washing out of soluble concrete components as a result of water penetration. 


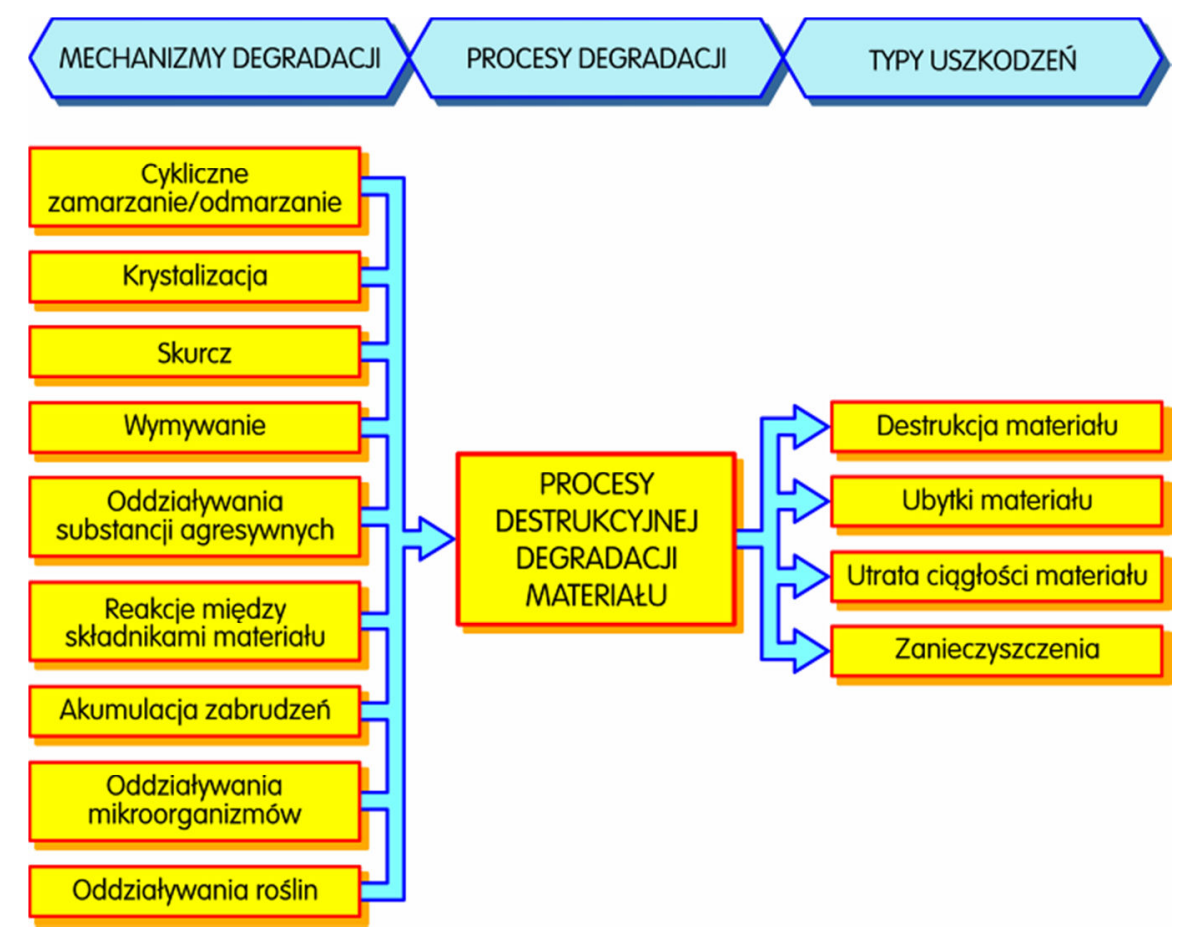

6. Basic mechanisms related to the processes of destructive degradation of reinforced concrete bridge structures and characteristic types of damage [3]

Concrete destruction may also be the result of chemical degradation mechanisms, which most often take the form of reactions between concrete components or reactions between concrete and aggressive substances acting from the outside. Destructive factors may also be related to biological mechanisms, such as the interaction of microorganisms or plants, or the accumulation of organic dirt. The effect of the mechanisms creating complex, usually, degradation processes are damage in the form of concrete destruction, and in more advanced stages of the process also in the form of losses or loss of material continuity.

Among the physical mechanisms of degradation, cyclic freezing and thawing of water in the concrete is of particular importance for the destructive processes of reinforced concrete structures. The increase in the volume of water that freezes in the pores of the concrete may cause significant additional stresses in the material (Table 5), leading to damage to its structure and resulting in a reduction in strength, local loss of continuity, and material losses (Fig. 7). A temperature change from $+4^{\circ} \mathrm{C}$ to $0^{\circ} \mathrm{C}$ causes an increase in the volume of freezing water by about $9 \%$ and a decrease in temperature to $-22^{\circ} \mathrm{C}$ causes an increase in the original volume by $13.2 \%$. This degradation mechanism is particularly active in temperate climate zones where many freezing and thawing cycles occur throughout the year. 
Tab. 5. Influence of water temperature changes on the pressure in concrete pores [13]

\begin{tabular}{|c|c|}
\hline Water temperature & Generated pressure \\
\hline$+4^{\circ} \mathrm{C}$ & 0 \\
\hline${ }^{\circ}{ }^{\circ} \mathrm{C}$ & $10 \mathrm{MPa}$ \\
\hline$-5^{\circ} \mathrm{C}$ & $61 \mathrm{MPa}$ \\
\hline$-10^{\circ} \mathrm{C}$ & $113 \mathrm{MPa}$ \\
\hline$-15^{\circ} \mathrm{C}$ & $159 \mathrm{MPa}$ \\
\hline$-20^{\circ} \mathrm{C}$ & $205 \mathrm{MPa}$ \\
\hline$-22{ }^{\circ} \mathrm{C}$ & $211,5 \mathrm{MPa}$ \\
\hline
\end{tabular}

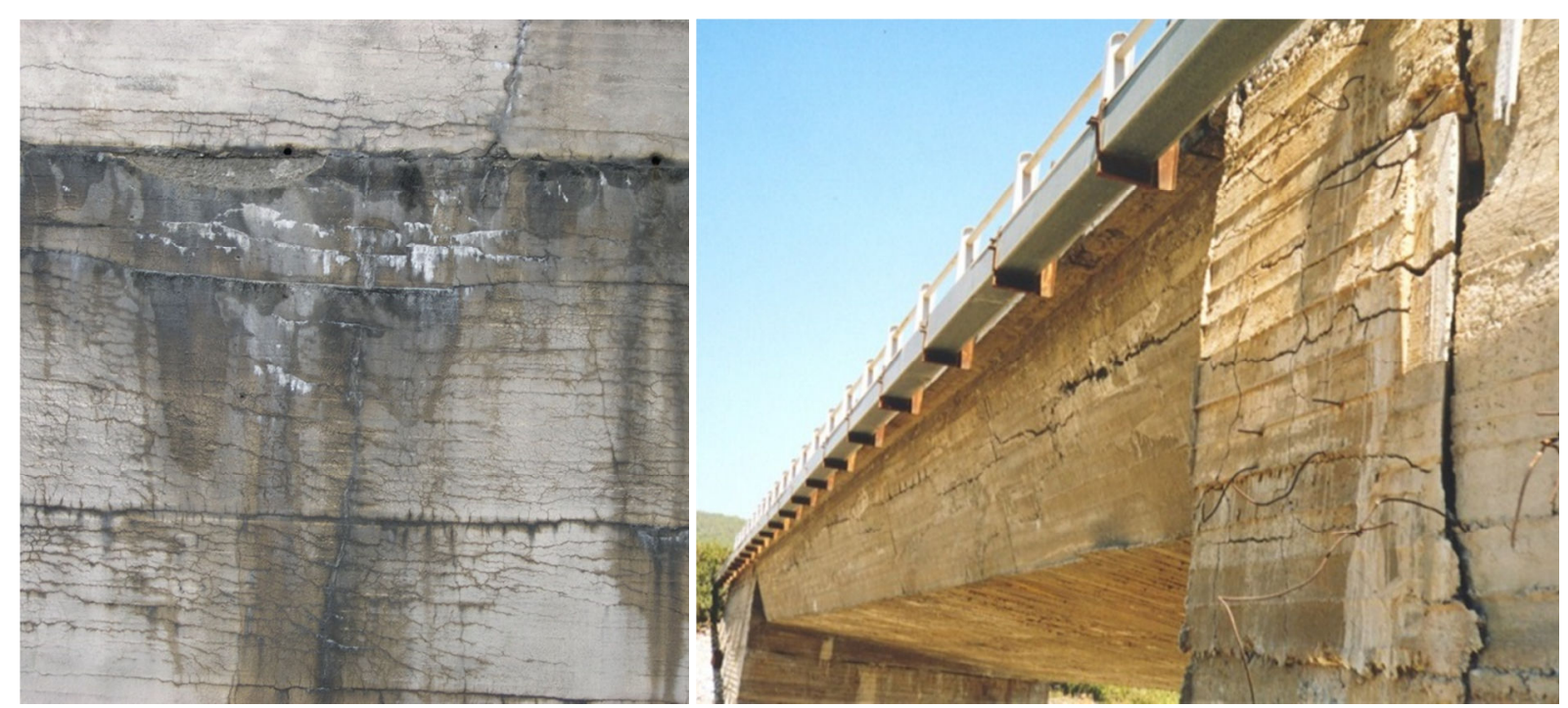

7. Examples of the destructive material degradation effects : concrete scratches and destruction caused by cyclic freezing/thawing of water and washing out of concrete components (left) and concrete shrinkage (right)

Fig. 7 also shows another example of the effects of the destructive material degradation process, where the main degradation mechanism was concrete shrinkage. The structure made in conditions of high temperature and low humidity was not provided with safeguards limiting the intensity of rheological processes during the setting and maturation of concrete. As a result, it led to the formation of numerous scratches and even fractures in the concrete (in many places with a significant width), as well as the destruction of the material.

\section{Processes of overload structures degradation}

The processes of overload degradation of a structure are related to the impact on the structure of loads exceeding the values for which it was designed, which in turn leads to deformation or changes in the position of structure elements, as well as to destruction, loss, or loss of material continuity (Fig. 8). This applies to both operational loads with values exceeding the design assumptions (e.g. oversize transports - see e.g. Fig. 9), excessive permanent loads resulting, for example, as a result of improperly performed repairs (Fig. 10), as well as loads resulting from floods, collisions, military operations, mining exploitation or earthquakes (Fig. 15). Excessive load on the structure may also be caused by the action of extremely high (e.g. as a result of fire) or low (e.g. extremely frosty winter conditions) temperatures. 


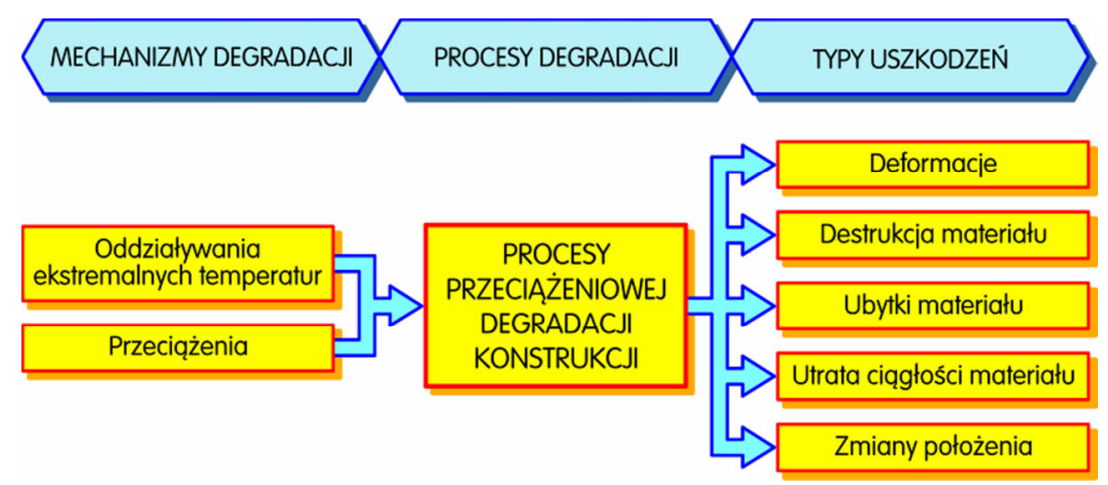

8. Basic mechanisms related to the processes of overload degradation of concrete bridge structures and characteristic types of damage [3]

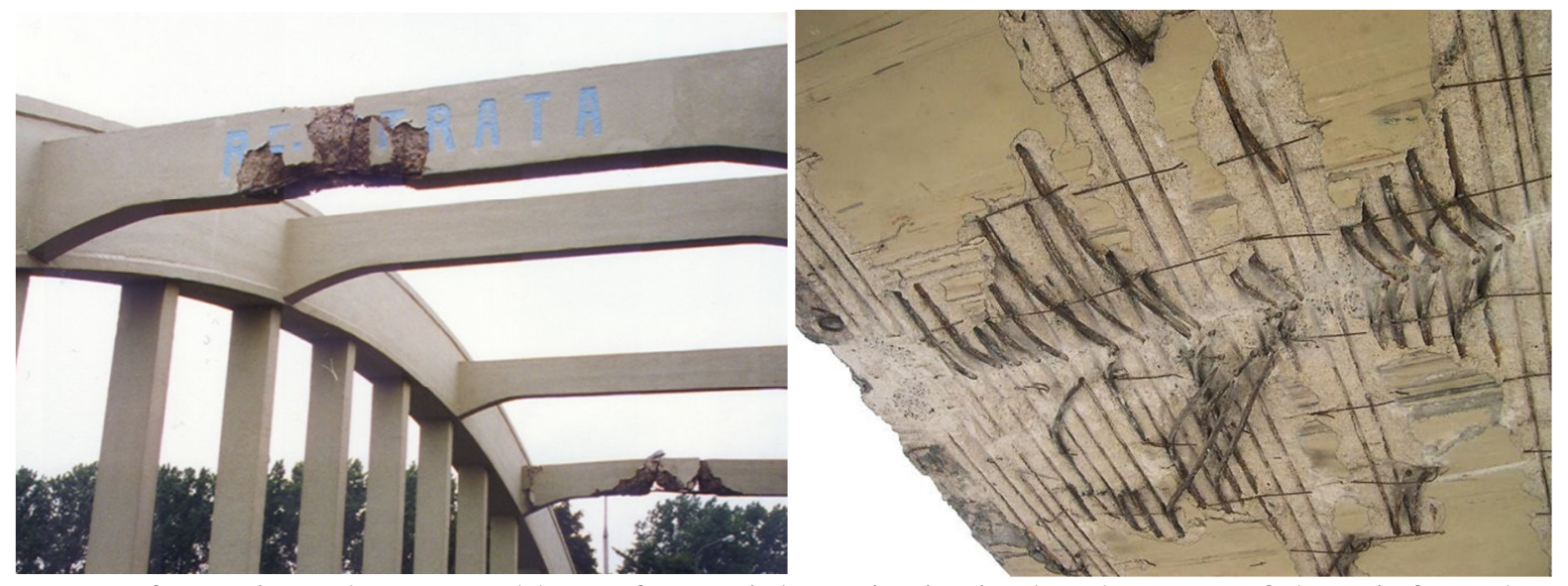

9. Deformations, losses, and loss of material continuity in the elements of the reinforced concrete bridge structure as a result of overloads caused by impacts of vehicles with oversize dimensions

Overload degradation processes are usually short-term phenomena and therefore are particularly dangerous both for the structure and its users. The lack of anticipatory symptoms signaling the initiation of processes and the very fast course of phenomena such as collisions, floods, or earthquakes usually make it impossible to take preventive measures.

\section{Damages of reinforced concrete bridge objects Hierarchical classification of damage}

The hierarchical classification of damage to reinforced concrete bridge structures, enabling their unambiguous systematization, according to the concept presented in [3], is presented in tab. 6.

In the presented classification, three basic levels of damage identification are distinguished:

- damage class (level I) - identified on the basis of definitions common to all types of bridge structures, design solutions and materials used in bridge structures,

- type of damage (level II) - which more precisely defines the nature of damage belonging to particular classes,

- damage category (level III) - specifying the specificity of the damage of a given class and type, in relation to the type of construction material.

At the highest level of the presented hierarchical classification system (level I), six basic classes of damage occurring in bridge structures of all categories were distinguished, regardless of the design solutions and materials used. 
Tab. 6. Hierarchical classification of damage to reinforced concrete bridge structures

\begin{tabular}{|c|c|c|}
\hline Damage class & Type of damage & Damage category \\
\hline \multirow{6}{*}{ Deformations } & \multirow{2}{*}{ Invalid feature geometry } & Incorrect concrete shape \\
\hline & & Incorrect reinforcement layout \\
\hline & \multirow{2}{*}{$\begin{array}{l}\text { Change the geometry of the } \\
\text { element axis }\end{array}$} & Excessive elastic deformation \\
\hline & & Continoues deformation \\
\hline & \multirow{2}{*}{$\begin{array}{l}\text { Change the geometry along the } \\
\text { element length }\end{array}$} & Excessive elastic deformation \\
\hline & & Continoues deformation \\
\hline \multirow{6}{*}{$\begin{array}{l}\text { Material } \\
\text { Destruction }\end{array}$} & \multirow{3}{*}{$\begin{array}{l}\text { Change in chemical } \\
\text { characteristics }\end{array}$} & Concrete characteristics change \\
\hline & & Change in the reinforcing steel characteristics \\
\hline & & Change in the protective layer material properties \\
\hline & \multirow{3}{*}{$\begin{array}{l}\text { Change in physical } \\
\text { characteristics }\end{array}$} & Concrete characteristics change \\
\hline & & Change in the reinforcing steel characteristics \\
\hline & & Change in the protective layer material properties \\
\hline \multirow{4}{*}{ Material losseS } & \multirow{2}{*}{ Loss of component material } & Concrete loss \\
\hline & & Reinforcing steel loss \\
\hline & \multirow{2}{*}{$\begin{array}{l}\text { Loss of material in the } \\
\text { protective layers }\end{array}$} & Concrete protection layers loss \\
\hline & & Loss of layers securing the reinforcing steel \\
\hline \multirow{6}{*}{$\begin{array}{l}\text { Loss of material } \\
\text { continuity }\end{array}$} & \multirow{3}{*}{ Scratch } & Concrete scratch \\
\hline & & Reinforcing steel scratch \\
\hline & & Protective layer material scratch \\
\hline & \multirow{3}{*}{ Fracture } & Concrete fracture \\
\hline & & Reinforcing steel fracture \\
\hline & & Protective layer material fracture \\
\hline \multirow{4}{*}{ Pollution } & \multirow{2}{*}{ Inorganic } & Agressive \\
\hline & & Neutral \\
\hline & \multirow{2}{*}{ Organic } & Agressive \\
\hline & & Neutral \\
\hline \multirow{4}{*}{$\begin{array}{l}\text { Changes in } \\
\text { location }\end{array}$} & \multirow{2}{*}{ Invalid linear displacement } & Excessive displacement \\
\hline & & Displacement limitation \\
\hline & \multirow{2}{*}{ Invalid rotation } & Excessive displacement \\
\hline & & Displacement limitation \\
\hline
\end{tabular}

Similarly, for all categories of objects, a common, uniform system of classification of types of damage (level II) can be used, which enables the identification of faults belonging to particular basic types to be more precisely identified. Damage categories, identified at the 3rd level of classification, largely depend on the specific properties of the construction material, so this classification level requires individualization with regard to individual construction materials. An exemplary three-level classification presented in tab. 7 concerns reinforced concrete structures.

\section{Deformations}

Deformation is a class of damage consisting of changes in geometry inconsistent with the design, causing changes in the relative distances of points on an object or its part. Among this type of damage, three types of deformation can be distinguished (see Table 6):

- $\quad$ incorrect geometry of the bridge structure element (Fig. 10 on the left),

- changing the geometry of the axis or the central surface of the element while maintaining the shape of the element in the cross-section (Fig. 10 on the right),

- change of element geometry in the cross-section, without deformation of the element axis (middle surface). 

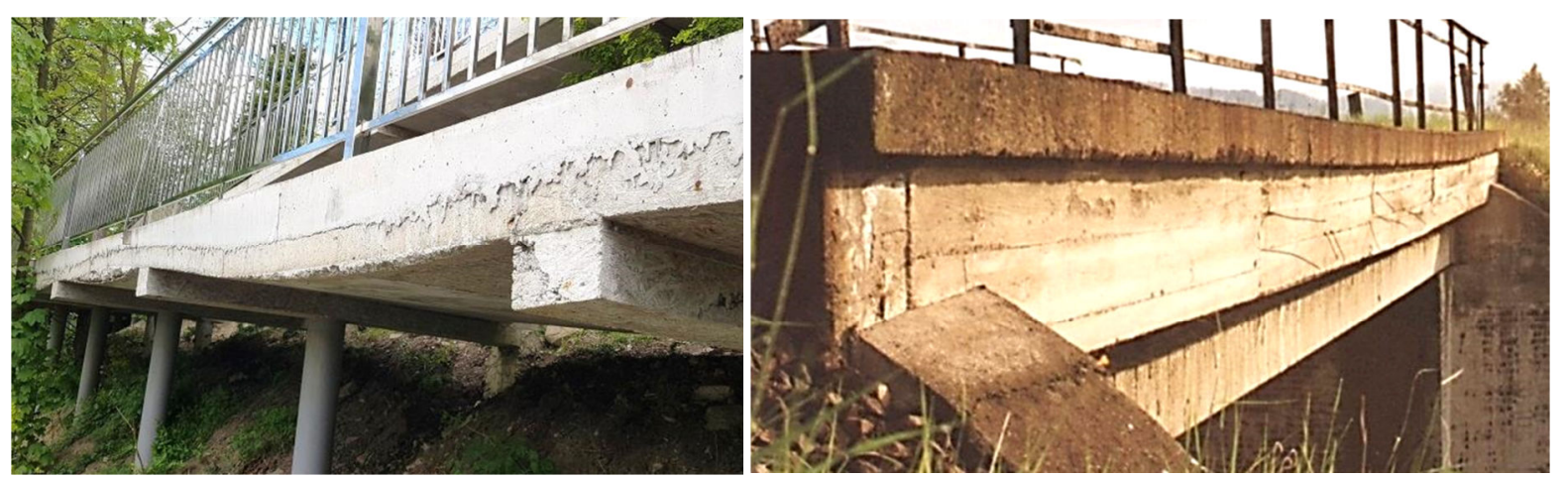

10. Deformations in the form of: incorrect structure geometry (on the left) and changes in the geometry of the element axis - permanent deflection of the span structure (on the right)

\section{Material destruction}

Material destruction is a class of damage consisting of the deterioration of the value of the physical and chemical properties of the material in relation to the designed values (see Table

6). Faults of this class can be divided into two basic types (Fig. 11):

- unfavorable changes in the chemical properties of the material compared to the designed values of these features,

- changes in the physical properties of the material leading to the deterioration of the condition of the bridge structure compared to the designed state.
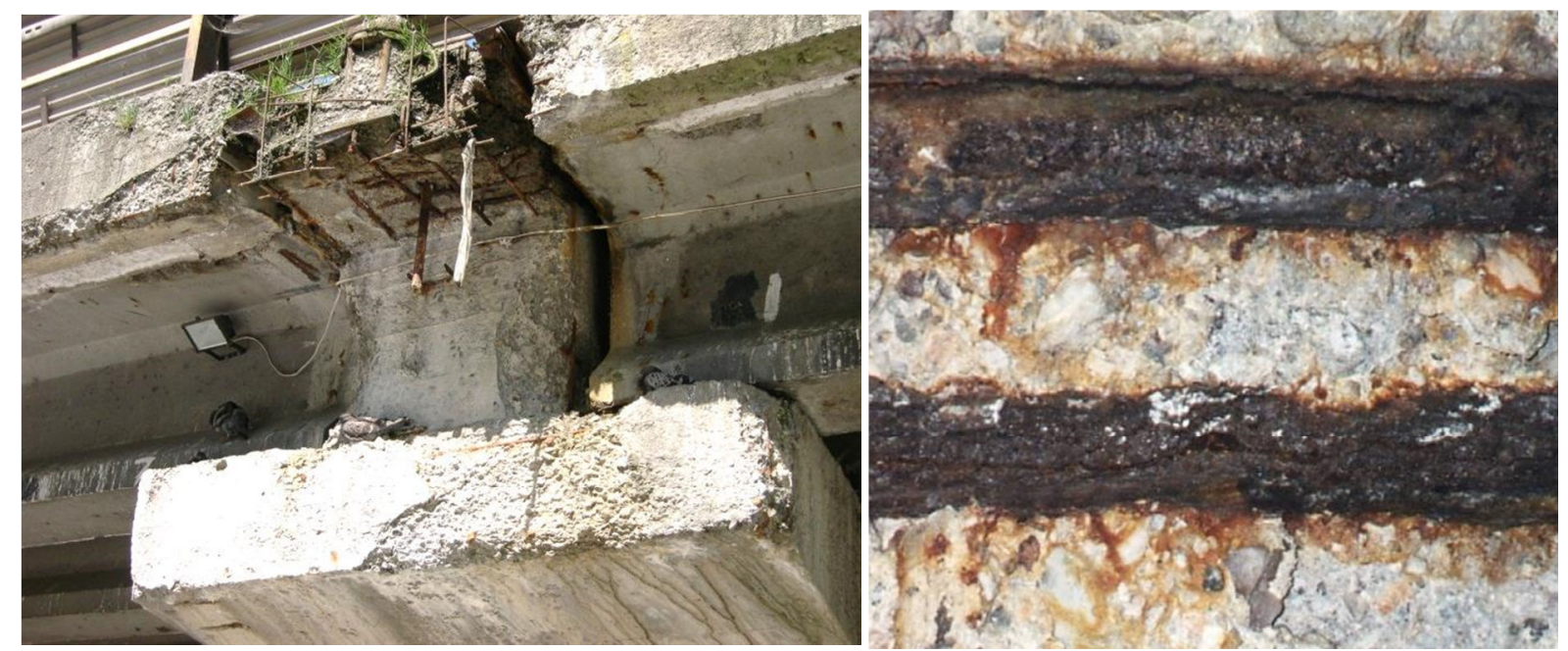

11. Destruction of concrete and steel of reinforcement bars in the form of deterioration of chemical and physical properties of materials - occurring simultaneously with material losses

\section{Material losses}

Loss of material is a common class of damage to reinforced concrete structures (Table 6), including damage consisting of a reduction in the amount of material of structural elements in relation to the designed solution. The basic types of this class of damage include losses in construction material (concrete, reinforcing steel) and losses in the material of the protective layers (Fig. 12). 

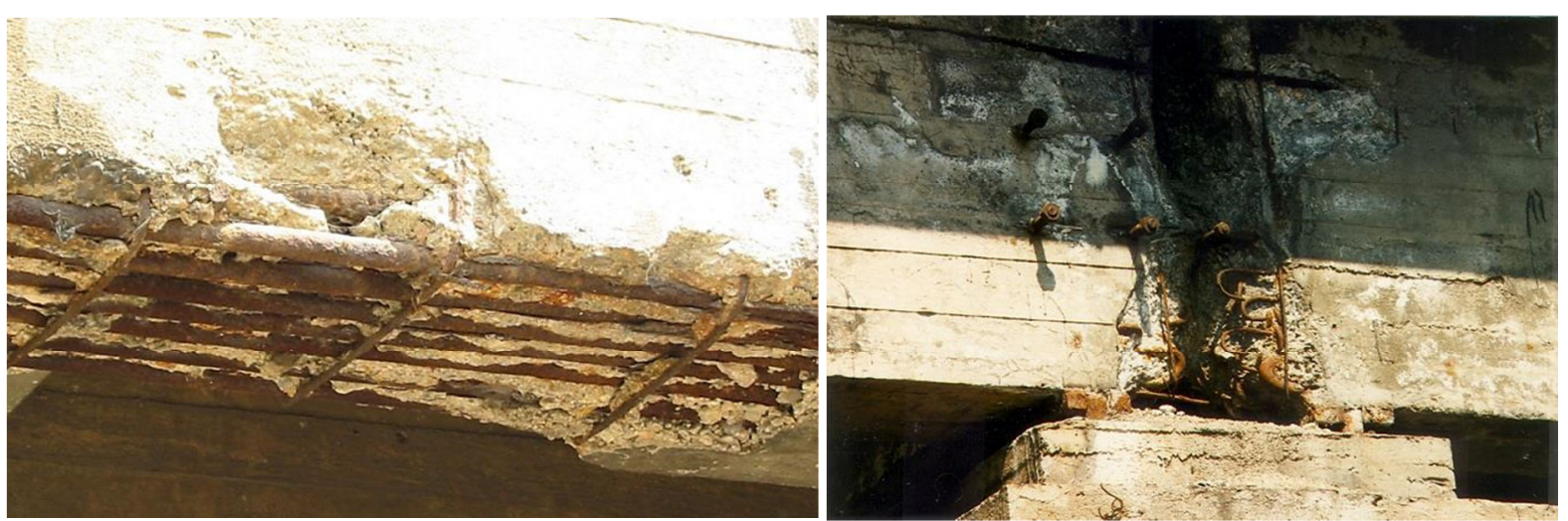

12. Loss of concrete in the protective layers and losses of reinforcing steel in bridge girders

\section{Loss of material continuity}

The class "loss of material continuity" includes damage consisting in breaking the continuity of the structure material contrary to the design (see Table 6). The basic types of damage included in this class are (Fig. 13):

- scratch, i.e. loss of material continuity in a part of the cross-section of a structure element,

- fracture, i.e. loss of continuity over the entire cross-sectional area of the element.
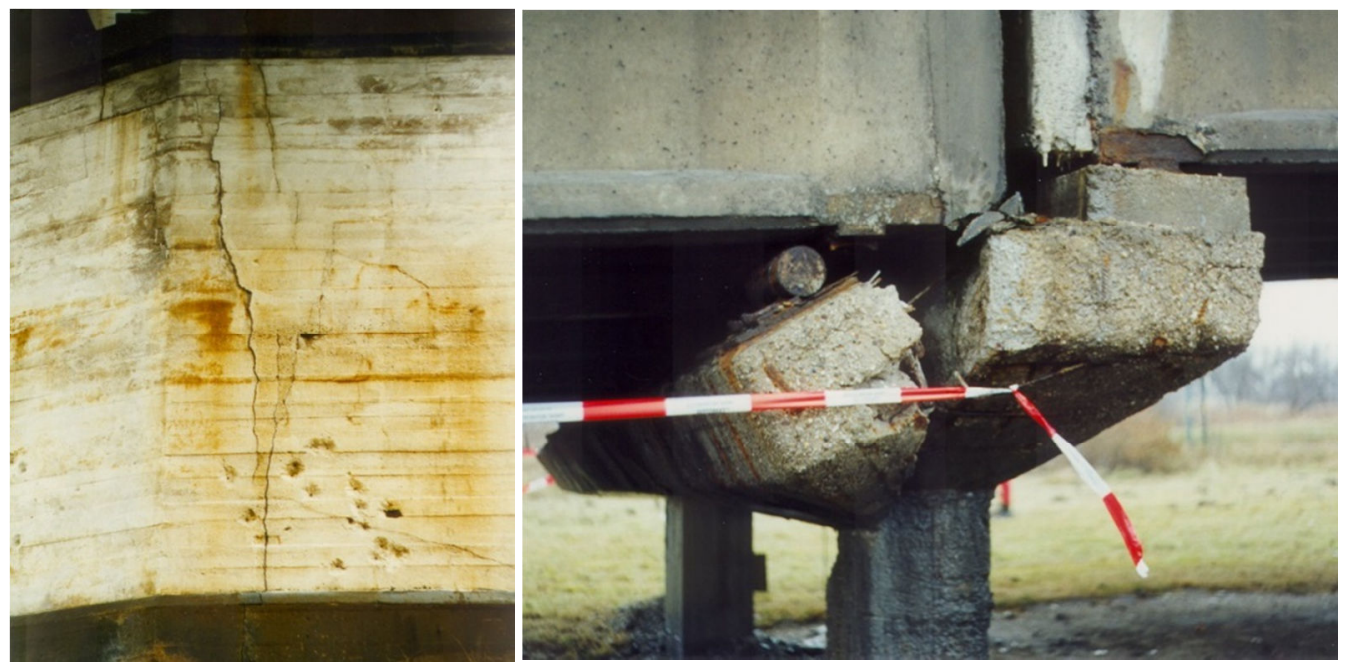

13. Loss of material continuity: scratches (left) and fracture (right)

\section{Contamination}

Contamination is a class of damage consisting of the presence of dirt in the object or the vegetation of plants or microorganisms on it not provided for in the project (Table 6). There are two basic types of damage belonging to this class (see Fig. 14):

- inorganic pollutants, which can be divided into two categories: aggressive pollutants, which initiate the degradation of the object and affect its course, and neutral pollutants, which mainly reduce the aesthetic value of the object,

- organic pollutants, including aggressive pollutants (e.g. vegetation of plants whose roots penetrate deep into the structure material) and neutral pollutants, affecting only the surface of the building's elements. 

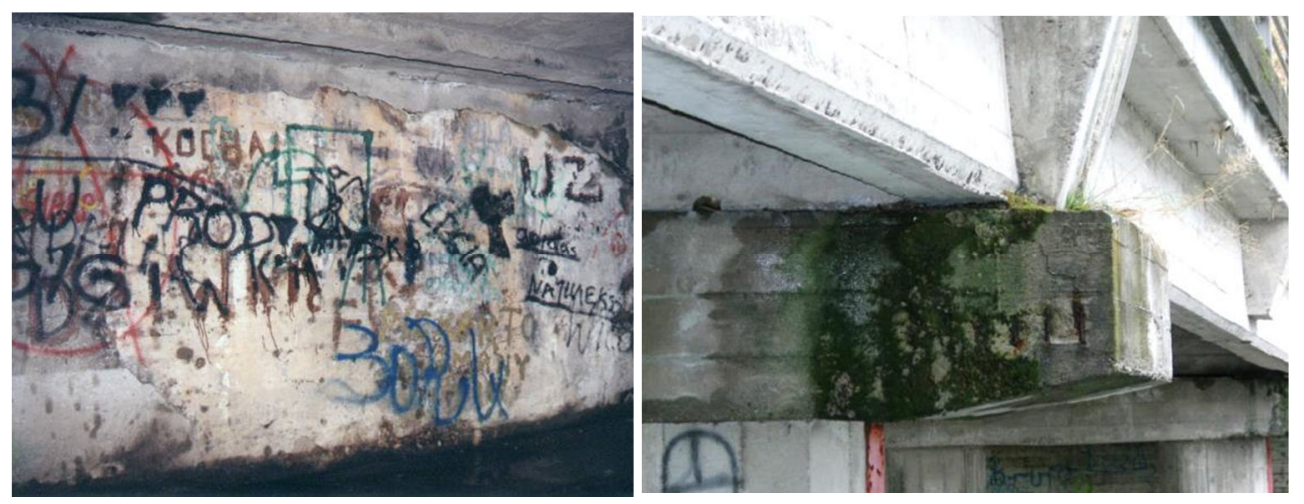

14. Neutral inorganic pollutants (left) and organic surface pollutants in the form of algae (right)

\section{Changes in location}

Changes in the position are a class of damage consisting in displacements of the bridge structure or its elements inconsistent with the design, at which the mutual distances of all points of the displaced part do not change, as well as limitation of the possibility of displacement inconsistent with the design (see tab. 6).

The following two basic types of damage consisting of changes of position in relation to the design solutions can be distinguished (see tab. 6):

- incorrect linear displacement of the object's elements, consisting in excessive displacement (in relation to the designed one) or limiting the possibilities of the designed linear displacements,

- incorrect rotation of the object's elements, manifested by an excessive value of rotation in relation to the designed conditions (see Fig. 15) or a limitation of the provided rotation possibilities.

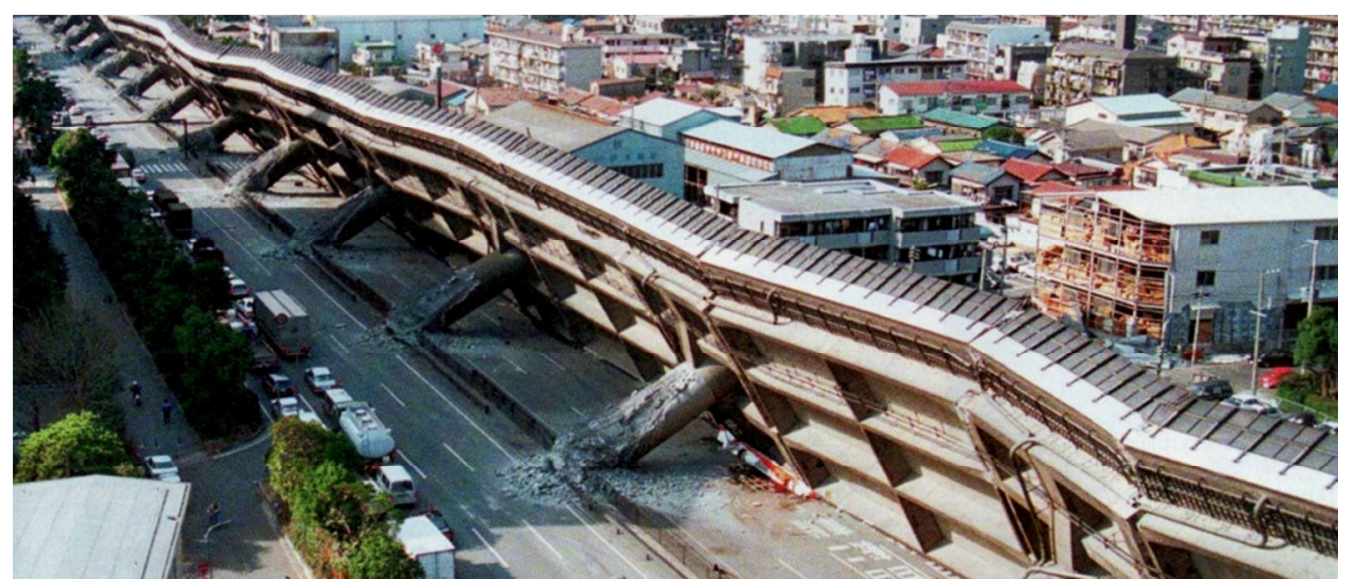

15. Changing the position (rotation) of the entire bridge structure as a result of an earthquake, combined with deformations as well as losses and loss of material continuity

\section{Summary}

The proposed classification of factors related to the phenomena of reinforced concrete bridge structures degradation is aimed at systematizing and standardizing the methods of identifying and describing the relationship between stimulators, mechanisms, and the processes of degradation and damage. The resulting damage is the result of individualized and usually complex degradation processes involving several degradation mechanisms. Detection and identification of damage and degradation mechanisms require the use of advanced diagnostic techniques and procedures using 
physical, chemical, and biological technologies, as well as modern interdisciplinary technologies. Detailed information on this subject is included, among others, in the works: $[3,4,5,7,8,12,20$, $21,22,23,26,28,30,31,36]$

In the presented system of hierarchical three-level classification of damage specific to reinforced concrete bridge structures (Table 6), 6 basic damage classes, 13 types of damage, and 30 damage categories were distinguished. The presented classification is open and can be easily supplemented with new classes, types, and categories of damage, as well as additional levels of classification enabling more detailed identification of damage. The relations between the activity of individual degradation mechanisms, typical for reinforced concrete structures, and the occurrence of damage belonging to individual classes are presented in tab. 7.

Tab. 7. Degradation mechanisms of reinforced concrete bridge structures and damage classes

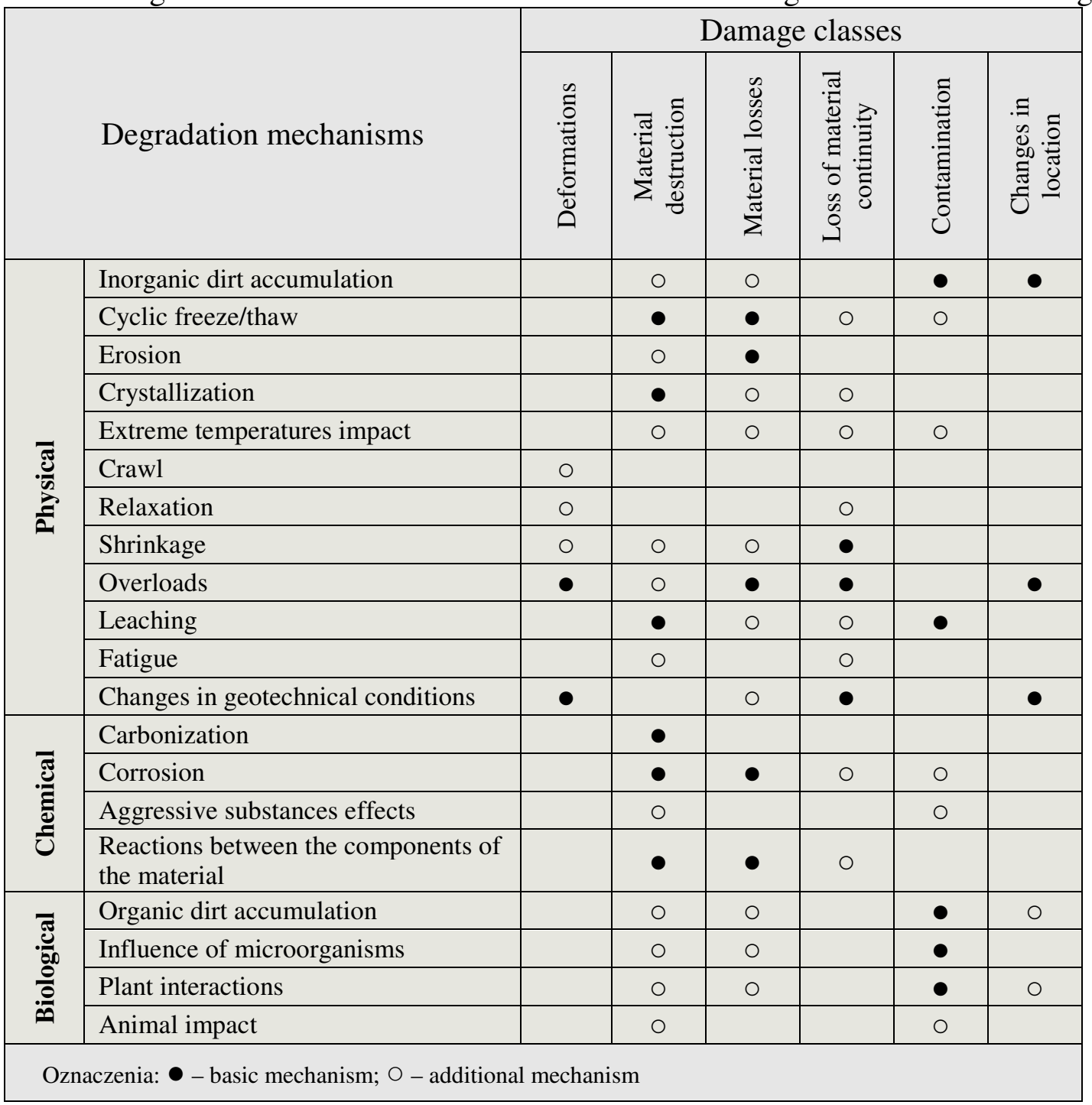

\section{Source materials}

[1] Bień J. Modelowanie obiektów mostowych w procesie ich eksploatacji. Oficyna Wydawnicza Politechniki Wrocławskiej, 2002.

[2] Bień J. Systemowe wspomaganie zarządzania mostami drogowymi i kolejowymi. Zeszyty Naukowe Politechniki Rzeszowskiej, 2012, Zeszyt 59, nr 3/12/I, s. 49-68. 
[3] Bień J. Uszkodzenia i diagnostyka obiektów mostowych. Wydawnictwa Komunikacji i Łączności, 2010.

[4] Bień J., Gładysz-Bień M. Klasyfikacja diagnostycznych badań obiektów mostowych. Inżynieria i Budownictwo, 2014, nr 7, s. 364-368.

[5] Bień J., Gładysz-Bień M. Multi-level classification of bridge defects in asset management. W: Towards a resilient built environment risk and asset management : IABSE Symposium 2019, Guimarães, Portugal, 2019, s. 1100-1107.

[6] Bień J., Jakubowski K., Kamiński T., Kmita J., Rawa P., Cruz P., Maksymowicz M. Railway bridge defects and degradation mechanisms, W: "Sustainable Bridges Assessment for Future traffic Demands and Longer Lives" (Eds: Bień J., Elfgren L., Olofsson J.), Wrocław 2007, s. 105-116.

[7] Bień J., Kamiński T., Kużawa M., Taxonomy of non-destructive field tests of bridge materials and structures. Archives of Civil and Mechanical Engineering. 2019, Vol. 19, No. 4, s. 1353-1367.

[8] Biliszczuk J., Bień J., Maliszkiewicz P., Mistewicz M., Onysyk J., Rabiega J. Podręcznik inspektora mostowego. Cz. 1 i 2, Politechnika Wrocławska, Instytut Inżynierii Lądowej, 1995.

[9] Biliszczuk J., Machelski Cz., Maliszkiewicz P., Mistewicz M. Typowe uszkodzenia drogowych betonowych mostów prefabrykowanych, Drogownictwo, 1994, nr 8, s. 186194.

[10] Biliszczuk J., Onysyk J., Węgrzyniak M. Typowe uszkodzenia masywnych podpór obiektów mostowych. Ochrona przed korozją, 1997, nr 1, s. 6-9.

[11] Błaszczyński T. Konstrukcje żelbetowe poddane działaniu produktów ropopochodnych, Wydawnictwo Politechniki Poznańskiej, 2004.

[12] Campbell D.H., Sturm R.D. and Kosmatka, S.H. Detecting Carbonation, Concrete Technology Today, 199, Vol. 12, Nr 1.

[13] CEB Design Guide to Durable Concrete Structures. Comite Euro-International du Beton, 1989.

[14] Choi S., Park S., Bolton R., Stubbs N., Sikorsky C. Periodic Monitoring of Physical Property Changes in a Concrete Box-Girder Bridge. Journal of Sound and Vibration, 2004, No. 278, s. 365-381.

[15] Corrosion of Steel in Reinforced Concrete Structures - COST 521. Final Report (Eds. Cigna R., Andrade C., Nürnberger U., Polder R., Weydert R., Seitz E.), European Commission, Directorate-General for Research, 2003.

[16] Czarnecki L., Emmons P.H. Naprawa i ochrona konstrukcji betonowych. Polski Cement Sp. z o.o., 2002.

[17] Failure, Distress and Repair of Concrete Structures (Ed.: Delatte N.), CRC Press, 2009.

[18] Flaga K. Wpływ czasu na mosty żelbetowe i $\mathrm{z}$ betonu sprężonego. Inżynieria i Budownictwo, 1997, nr 6, s. 381-382.

[19] Furtak K., Śliwiński J. Materiały budowlane w mostownictwie. WKŁ, 2004.

[20] Hellier Ch.J. Handbook of nondestructive evaluation. McGraw-Hill, 2001.

[21] Helmerich R., Bień J., Cruz P. A guideline for inspection and condition assessment including the NDT-toolbox. W: "Sustainable Bridges - Assessment for Future traffic Demands and Longer Lives" (Eds: Bień J., Elfgren L., Olofsson J.), Wrocław 2007, s. 93-104.

[22] Hoła J., Bień J., Sadowski L., Schabowicz K. Non-destructive and semi-destructive diagnostics of concrete structures in assessment of their durability. Bulletin of the Polish Academy of Sciences Technical Sciences, 2015, Vol. 63, Issue 1, s. 87-96. 
[23] Kurdowski W., Garbacik A. Najczęstsze błędy w ocenie przyczyn uszkodzeń betonu i jego zagrożenia awarią, XXIII Konferencja Naukowo-Techniczna „Awarie Budowlane", Szczecin-Międzyzdroje, 2007, s. 81-92.

[24] Libudzisz Z. Mikrobiologia techniczna. Wydawnictwo Politechniki Łódzkiej, 2000.

[25] Łakomy T. Korozja zbrojenia w obiektach mostowych w zależności od stanu betonu w konstrukcji (rozprawa doktorska), Politechnika Warszawska, Wydział Inżynierii Lądowej, 2009.

[26] Malhorta V.M., Carino N.J. CRC Handbook on nondestructive testing of concrete, CRC Press, 2003.

[27] PN-EN 14630:2007. Wyroby i systemy do ochrony i napraw konstrukcji betonowych. Metody badań. Oznaczanie głębokości karbonatyzacji w stwardniałym betonie metodą fenoloftaleinową.

[28] Runkiewicz L. Badania konstrukcji żelbetowych. Biuro Gamma, 2002.

[29] Runkiewicz L. Wpływ błędów projektowych i realizacyjnych na korozję i awaryjność obiektów budowlanych. Ochrona przed Korozją, 2004, nr 5s/A, s. 229-234.

[30] Schweitzer P.A. Fundamentals of Corrosion: Mechanisms, Causes, and Preventative Methods. CRC Press, 2009.

[31] Shull P.J. Nondestructive evaluation: theory, techniques and applications. Marcel Dekker, Inc., 2002.

[32] Ściślewski Z. Ochrona konstrukcji żelbetowych. Arkady, 1999.

[33] Wieczorek G. Korozja zbrojenia inicjowana przez chlorki i karbonatyzację otuliny. Dolnośląskie Wydawnictwo Edukacyjne, 2002.

[34] Zobel H., Alkhafaji T., Wróbel M. Określanie trwałości mostów drogowych. Mosty, 2007, nr 2, s. 40-54.

[35] Zobel H.: Naturalne zjawiska termiczne w mostach. WKŁ, 2002.

[36] Zybura A., Jaśniok T. Diagnostyka stanu korozyjnego zbrojenia w żelbetowych obiektach komunikacyjnych. Drogownictwo, 2000, nr 4, s. 109-116.

[37] Zyska B. Katastrofy, awarie i zagrożenia mikrobiologiczne w przemyśle i budownictwie. Wydawnictwo Politechniki Łódzkiej, 2001.

[38] Zyska B. Mikrobiologiczna korozja materiałów. Wydawnictwa Naukowo-Techniczne, 1977. 